\title{
Therapeutic options in AIDS related Kaposi's sarcoma: a 5-year Nigerian review
}

\author{
AA Babadoko*1, MS Shehu ${ }^{2}$, SM Aminu ${ }^{1}$ and AM Suleiman ${ }^{1}$
}

Address: ${ }^{1}$ Department of Haematology and Blood Transfusion, Ahmadu Bello University Teaching Hospital, Zaria, Nigeria and ${ }^{2}$ Department of Histopathology, Ahmadu Bello University Teaching Hospital, Zaria, Nigeria

* Corresponding author

from I I th International Conference on Malignancies in AIDS and Other Acquired Immunodeficiencies (ICMAOI): Basic, Epidemiologic, and Clinical Research

Bethesda, MD, USA. 6-7 October 2008

Published: 17 June 2009

Infectious Agents and Cancer 2009, 4(Suppl 2):P8 doi:I0.II86/1750-9378-4-S2-P8

This abstract is available from: http://www.infectagentscancer.com/content/4/S2/P8

(c) 2009 Babadoko et al; licensee BioMed Central Ltd.

\section{Objective}

To assess the beneficial effects of some of the available therapeutic agents in the management of AIDS-related Kaposi's sarcoma in a resource limited setting.

\section{Patients/methods}

The study was conducted between 2003 and 2007 at Ahmadu Bello University Teaching Hospital, a tertiary referral center in Zaria, Nigeria. There were 37 histologically diagnosed KS. All the cases were HIV-1 antibody positive by parallel ELISA method (Immunocomb and Genie II). Complete blood count was carried out by either standard manual and automated methods (Advia ${ }^{\circledR} 60$ ). CD4+ T lymphocytes enumerated using Dynabeads or Cyflow. Facilities for KS herpes virus type 8 serological screening were not available. Other ancillary investigations were carried out. The modalities of treatment include antiretroviral therapy (ART), Chemotherapy and Surgical excision.

\section{Results}

During a 5-year period, 37 antiretroviral naïve patients were recruited into this study. Men were predominantly affected, with a male to female ratio of 2.3:1. Cutaneous lesions were the earliest and commonest mode of presentation in all the patients. Visceral involvement could not be assessed due to lack of appropriate endoscopic biopsy tools. The mean packed cell volume was 0.28 and a mean CD4+ T Lymphocyte counts of 262.6-cells/ $\mu$ l of blood. Eight patients died pre-evaluation to commencement of any form of therapy due to late hospital presentation (extensive and progressive disease), nine patients were lost to follow up after commencement of ART and or chemotherapy. Five patients who had localized cutaneous KS lesions were on ART alone. Of the remaining 15 that had chemotherapy, five had single agent (Vincristine 1.4 $\mathrm{mg} / \mathrm{m} 2$ every 2 weeks for six cycles) at $\$ 12$ per cycle and only one had vinblastine alone, while eight had polychemotherapy, (Adriamycin $10 \mathrm{mg} / \mathrm{m} 2$, Bleomycin $10 \mathrm{U} / \mathrm{m} 2$ and Vincristine $1.4 \mathrm{mg} / \mathrm{m} 2$ every 2 weeks for six cycles except for one who discontinued due to cost) at $\$ 89$ per cycle. Complete remission was achieved in two patients and partial remission in the remaining six patients that received polychemotherapeutic ABV regimen (partial remission defined as 50 percent regression in tumor size, improvement in clinical status and CD4 count) compared to those who had single agent chemotherapy or ART alone (no remission was achieved). The last patient was a 9year-old girl who was treated with ART and surgical excision of the localized lesions. Management is hampered by late hospital presentation, presence of other co-morbid conditions such as tuberculosis, affordability and availability of the recommended choice of therapeutic agents in country where majority of the population subsists on less than $\$ 1$ per day.

\section{Conclusion}

These finding suggest that ABV regimen remains an effective treatment option in resource limited settings where the internationally approved chemotherapeutic agents such as Paclitaxel, Liposomal doxorubicin and immune 
modulators (alpha interferon) are beyond the reach of the majority of the population.

Publish with Bio Med Central and every scientist can read your work free of charge

"BioMed Central will be the most significant development for disseminating the results of biomedical research in our lifetime. " Sir Paul Nurse, Cancer Research UK

Your research papers will be:

- available free of charge to the entire biomedical community

- peer reviewed and published immediately upon acceptance

- cited in PubMed and archived on PubMed Central

- yours - you keep the copyright

Submit your manuscript here:

http://www.biomedcentral.com/info/publishing_adv.asp 